\title{
Die Christelike grondmotief en die Heilige Skrif by Dooyeweerd
}

\author{
Jacques Roets \\ Departement Filosofie \\ Potchefstroomse Universiteit vir $\mathrm{CHO}$ \\ POTCHEFSTROOM
}

\begin{abstract}
The Christian ground motive and Holy Scripture in Dooyeweerd

In this article it will be argued that a relationship exists between the supratemporal sphere and the Christian ground motive, as well as between the temporal sphere and Holy Scripture. This relationship leads to the view that the Christian ground motive is the one, undivided, eternal Word of God, while Scripture is the temporal, diversified expression of this one, undivided, eternal Word of God. The association of the supratemporal sphere and the Christian ground motive gives rise to a degree of absolutism in Dooyeweerd. For Dooyeweerd the Christian ground motive is supratemporal while theoretical thought is always bound to the temporal horizon. By distinguishing between the Christian ground motive, our philosophical thinking about it, and our sinful human formulation of it we can rid Dooyeweerd of this absolutism.
\end{abstract}

\section{Inleiding}

Een van die belangrikste probleme waarmee die Christelike filosofie hom kan besig hou, is die verhouding tussen wetenskap (spesifiek filosofie) en die geskrewe Woord van God (Skrif). Die probleem is belangrik, omdat die geskrewe Woord van God so 'n sentrale en fundamentele rol in die Christen se daaglikse lewe speel. William Hendriksen (1991:302), in sy kommentaar op 2 Timoteus 3:16, beeld die sentrale rol van die Skrif in die Christen se lewe gepas uit as hy sê: “"all Scripture'... constitutes the infallible rule of faith and practice for mankind". Geen Christenfilosoof kan daaraan ontkom om te besin oor wat die invloed van die geskrewe Woord van God op sy werk is of behoort te wees nie. Die invloed en rol wat Christenfilosowe aan die geskrewe Woord van God in hulle filosofie 
Die Christelike grondmotief en die Heilige Skrif by Dooyeweerd

toeken, sal verskil na gelang van hulle verskillende visies op die Skrif en op die werklikheid.

In hierdie artikel gaan na Herman Dooyeweerd, een van die grondleggers van die Wijsbegeerte der Wetsidee, se antwoord op hierdie (wetenskaps)filosofiese vraag gekyk word. Soos enige filosoof is sy antwoord op die probleem baie sterk deur sy eie (Skrifmatige) ontologie bepaal. Die probleem kan dus nie op enige manier aan Dooyeweerd gestel word nie, aangesien sekere vrae vir sy ontologie non-vrae is; daarom moet die vraag 'Wat is die verhouding tussen filosofie en die Skrif?' omvorm word om by Dooyeweerd se ontologie aan te pas. Die vraag wat aan hom gevra moet word, is: 'Waaraan ontleen die Wysbegeerte van die Wetsidee sy Skriftuurlike aard?' Op hierdie vraag antwoord Dooyeweerd (1950:3) duidelik dat die Wysbegeerte van die Wetsidee sy Skriftuurlike aard uitsluitlik grond op wat dié filosofie die religieuse grondmotief van die Woordopenbaring noem, naamlik die motief van skepping, sondeval en verlossing deur Jesus Christus in gemeenskap met die Heilige Gees.

Op grond van sy antwoord kom die volgende vraag na vore - die probleem waaroor hierdie artikel handel - wat is die verhouding tussen die grondmotief van die Woordopenbaring (of Christelike grondmotief) en die Heilige Skrif by Dooyeweerd?

\section{Agtergrond tot die verhouding tussen die Christelike grondmotief en die Heilige Skrif}

\subsection{Die tydsonderskeid}

Dooyeweerd onderskei tussen 'n tydelike en 'n bo-tydelike sfeer in die skepping. Hierdie onderskeid neem 'n sentrale plek in sy ontologie in, soos duidelik blyk uit die bespreking van Olthuis (1985:23-24).' Inderdaad sê Dooyeweerd (1957:28) self in sy New Critique dat "the idea of cosmic time constitutes the basis of the philosophical theory of reality in this book".

Volgens Dooyeweerd (1957:16) is die eenheid en totaliteit van die sinverskeidenheid bo-tydelik, dit wil sê die eenheid en totaliteit van die sinverskeidenheid is transendent en onderskeie van die sin-verskeidenheid van

$1 \quad$ Ouweneel $(1993 a: 213,220)$ toon aan dat Dooyeweerd se tydsbeskouing so sentraal in sy filosofie staan dat daar nie daarvan afstand gedoen kan word sonder om sy hele sistematiese denke te verwring nie. 
die tydelike empiriese werklikheid. Sowel die bo-tydelike eenheid as die tydelike verskeidenheid val binne die geskape kosmos. Om hulle verhouding te verduidelik gebruik hy die volgende metafoor (Dooyeweerd, 1957:102): net soos 'n prisma lig opbreek in sy ryke verskeidenheid van kleure, breek die tyd die sin-volheid van die skepping op in 'n ryke verskeidenheid van aspekte. Terwyl die wet die grens tussen God en die skepping is, is die tyd die grens tussen die bo-tydelike sentrale sfeer van die menslike bestaan, waardeur die goddelike openbaring kom (1957:33), en die temporele sin-verskeidenheid van die empiriese werklikheid.

Dooyeweerd (1957:106) gaan ook verder en sê dat "the fulness of meaning, as totality and radical unity, is not actually given and cannot be actually given in time". Die temporele sin-samehang veronderstel eerder sy dieper identiteit in 'n bo-tydelike religieuse worteleenheid (Dooyeweerd, 1957:79). In hierdie religieuse worteleenheid - wat die Skrif die 'hart' noem - kom die temporele sin-verskeidenheid tot 'n radikale eenheid, aangesien God die totale temporele bestaan van die mens in die bo-tydelike hart gekonsentreer het. Die totale temporele bestaan moet vanuit die hart op sy Oorsprong gefokus word (Dooyeweerd, 1957:55). ${ }^{2}$

Die tydelike:bo-tydelike skema staan dus baie sentraal in Dooyeweerd se filosofie.

\subsection{Die religieuse grondmotiewe}

Nog ' $n$ belangrike element van Dooyeweerd se ontologie is die religieuse grondmotiewe. Wat is 'n religieuse grondmotief? Dooyeweerd beantwoord hierdie vraag in sy boek Roots of Western Culture (1979). Hy som die antwoord op hierdie vraag onder die volgende vier punte op:

* In elke religie funksioneer 'n grondmotief. So 'n grondmotief is die geestelike krag wat as die absolute bron van die menslike

2 Vir 'n opsomming van al die bo-tydelike elemente in Dooyeweerd se filosofie kan Kraay (1980:13) geraadpleeg word.

Ouweneel (1993a:215) meen dat Dooyeweerd se woordkeuse tot baie misverstande lei en stel voor dat bo-tydelikheid vervang word met plenitemporality of vol-tydelikheid. Hierdie woordkeuse sal daar toe lei dat bo-tydelik (voltydelikheid) nie verwar word met terme soos ekstra-temporele, nie-temporele, of selfs anti-temporele nie. Die term vol-tydelikheid grens homself dus aan die een kant af van die ewigheid, en aan die ander kant van die tydelike modale verskeidenheid. 
Die Christelike grondmotief en die Heilige Skrif by Dooyeweerd

samelewing dien. Hierdie grondmotief beheer die hele tydelike bestaan van die mens vanuit die religieuse sentrum (bo-tydelike hart), deur dit te rig op die ware of valse Oorsprong van die skepping (Dooyeweerd, 1979:9, 30, 41, vgl. 16-17).

* ' $n$ Gees is direk werksaam in 'n religieuse grondmotief. Hierdie gees is óf die Gees van God óf 'n afgod. Die mens vertrou op hierdie gees as bron en onwrikbare grond van sy bestaan; hy plaas homself in diens van dié gees (Dooyeweerd, 1979:9, 12-13, 30, 40).

* 'n Religieuse grondmotief is 'n gemeenskapsmotief. 'n Religieuse grondmotief dryf ' $n$ hele gemeenskap en beheer elke individu daarin, selfs al is hulle nie daarvan bewus nie (Dooyeweerd, 1979:9, 30).

* ' 'n Religieuse grondmotief kan nooit die objek van 'n wetenskaplike ondersoek wees nie. Wetenskap bestudeer slegs die temporele werklikheid, terwyl 'n grondmotief bo-tydelik is. Wetenskap word deur 'n bepaalde religieuse grondmotief gerig, dit wil sê wetenskap kan nooit neutraal wees ten opsigte van religie nie (Dooyeweerd, 1979:9, 12).

\section{Die verhouding tussen die Christelike grondmotief en die Heilige Skrif}

Dooyeweerd (1957:59) meen dat teoretiese denke 'n religieuse vertrekpunt het. God het die hart van die mens sy religieuse beheersentrum gemaak deur die mens se totale temporele bestaan in sy hart te konsentreer. Vanuit hierdie bo-tydelike religieuse sentrum word die totale temporele bestaan van die mens (ook sy wetenskapsbeoefening) op God of 'n afgod gerig (Dooyeweerd, 1957:55). Dié gerigtheid van die hart word bepaal deur watter grondmotief dit in beslag geneem het; daarom kan Dooyeweerd (1979:13) sê dat "science is always determined by a religious ground motive".

Volgens Dooyeweerd (1950:3) moet Christelike wetenskaplikes hulle laat lei deur die Christelike grondmotief van skepping, sondeval en verlossing deur Jesus Christus in gemeenskap met die Heilige Gees. Hierdie grondmotief lê beslag op die menslike hart en rig dit op God (Dooyeweerd, 1957:5, 60-61). Dooyeweerd (1979:35; vgl. 1960:103) verduidelik self die werking van die Christelike grondmotief soos volg:

The scriptural ground motive of the christian religion ... reveals to us that the soul or spirit of man is the absolute central root unity or the heart of the 
whole of his existence, because man has been created in God's image; further, it reveals that man has fallen away from God in the spiritual root of his existence; and, finally, that in the heart or focal point of his existence man's life is redirected to God through Christ's redemptive work.

Die feit dat die grondmotief beslag lê op die bo-tydelike hart verklaar waarom Dooyeweerd $(1979: 9,12)$ kan sê dat die grondmotief nie die voorwerp van teoretiese denke kan wees nie. Inteendeel, teoretiese denke, wat een van die tydelike funksies van die mens is, word deur die grondmotief beheer (vergelyk Dooyeweerd, 1979:94).

Dooyeweerd (1979:95-96) verduidelik hierdie uitgangspunt treffend in die volgende woorde:

This biblical ground motive is not a theoretical truth which one can understand scientifically. Rather, it is the all-controlling, dynamic power of God's Spirit who must open our hearts to what God has to say to us ...

Wetenskap bly altyd volgens Dooyeweerd (1957:39) verbonde aan die Gegenstand-relasie waarin die tydelike logiese aspek van ons denke teenoor 'n tydelike nie-logiese aspek van ons ervaring geplaas word. Die Gegenstand-relasie kan slegs binne die tydelike sfeer tot stand kom, aangesien die tyd verantwoordelik is vir die opbreek van die bo-tydelike religieuse sin-volheid (van die hart) in verskillende temporele modale aspekte (Dooyeweerd, 1957:102). Die Christelike grondmotief werk in die hart van die mens, en daarom het dit dus ook die kenmerk van botydelikheid (Dooyeweerd, 1980:82-83). Die Christelike grondmotief oorskry dus - nes die hart - die perke van teoretiese denke - insluitend die teologie (Dooyeweerd, 1958:4).

Dooyeweerd (1958:4) motiveer die rede waarom die Christelike grondmotief in sy sentrale religieuse sin die perke van alle teologiese problematiek te bowe gaan soos volg:

\footnotetext{
Maar de centrale en radicale religieuze zin van de openbaring van schepping, zondeval en verlossing door Christus Jezus in de gemeenschap van de $\mathrm{H}$. Geest gaat alle theologische problematiek te boven, omdat die alle modaliteiten van onze tijdelijke ervaringshorizon transcendeert. Het verstaan van die centrale zin is slechts mogelijk, indien wij ons door de werking van de $\mathrm{H}$. Gees in de greep van Gods Woord bevinden, zodat het werkelijk de centrale drijfkracht van ons denken en leven is geworden. De Gods- en zelfkennis, die daarin ons deel wordt, is een kennis des harten, die ons werkelijk in gemeenschap brengt met God in Christus Jezus en daarom een kwestie is van leven of dood, en niet van theoretisch theologisch inzicht en theologische problematiek.
} 
Die Christelike grondmotief en die Heilige Skrif by Dooyeweerd

In hierdie aanhaling van Dooyeweerd kan gesien word hoe sy onderskeid tussen die tydelike en die bo-tydelike sfeer inwerk op sy denke. Alles wat bo-tydelik is, is verhewe bo teoretiese denke; daarom sê hy dat die Christelike grondmotief nie 'n geloofstuk of dogma is nie, aangesien geloofstukke of dogmas aan verskillende teologiese (tydelike) interpretasies verbonde is. Die grondmotief is eerder die gemeenskaplike uitgangspunt van alle Christelike denke en handelinge - 'n uitgangspunt wat as goddelike dunamis ook aan die Christelike geloofsleer gees en lewe gee (Dooyeweerd, 1958:4).

Nog 'n faset van sy denke wat vir die verhouding tussen die Christelike grondmotief en die Heilige Skrif baie belangrik is, is sy onderskeid tussen Woord van God in die sentrale religieuse sin en die Woord van God soos dit binne die verskillende modale aspekte van ons temporele ervaring gegee is (Dooyeweerd, 1968:132, 136). In die vorige aanhaling praat hy van die grondmotief as openbaring. Die Christelike grondmotief is volgens Dooyeweerd (1958:4; 1968:143-144) die Woordopenbaring in die sentrale religieuse sin, terwyl die Heilige Skrif en Christus die Woord van God in ons tydelike ervaringshorison is. As 'n mens Dooyeweerd oppervlakkig lees, sal jy nie maklik hierdie onderskeid raaksien nie - dit kan daartoe lei dat die Christelike grondmotief soms verwar word met die Heilige Skrif. 'n Voorbeeld van dié verwarring vind 'n mens by Duvenage (1984:55-56). In sy artikel oor die plek van die Skrif in die wetenskap sê hy die volgende oor Dooyeweerd:

Met die oog op die totstandkoming van Christelike wetenskap is dit nodig dat die religieuse grondmotief van die Bybel, nl. skepping, sondeval en verlossing, op die hart as religieuse sentrum beslag lê. En via die hart kry die Skrif as openbaring dan plek.

Uit dié aanhaling sien 'n mens dus duidelik dat Duvenage die grondmotief en die Skrif as dieselfde ding sien, terwyl Dooyeweerd dié twee duidelik onderskei.

Hierdie onderskeid word ook deur Dooyeweerd se tydsbeskouing beïnvloed. Die Woord van God in sy sentrale religieuse sin rig hom tot die botydelik hart van die mens en daarom is dit verhewe bo alle teoretiesteologiese interpretasie (Dooyeweerd, 1960:104). Daarteenoor het die Woord van God in sy temporele gestalte deel aan die groot verskeidenheid 
modale aspekte wat binne ons temporele ervaringshorison gevind word (Dooyeweerd, 1958:3-4).

Die sentrale grondmotief van die Woordopenbaring kan egter nie geskei word van die Woordopenbaring wat in ons tydelike ervaringshorison gegee is nie. 'Die sentrale religieuse Woordopenbaring word in die vleeswording van die Woord, in Christus en die Heilige Skrif vervul (Dooyeweerd, 1968:143-144). Nogtans doen die eenheid van die Woord van God nie afbreuk aan die onderskeid tussen die sentrale motief van die Skrif as goddelike dryfkrag, wat hom rig tot die hart, die sentrale worteleenheid van ons werklikheid en die beliggaming daarvan binne die tydelike orde van ons ervaringshorison met sy ryke verskeidenheid modale aspekte nie (Dooyeweerd, 1958:4).

Dooyeweerd (1958:3) vat hierdie onderskeid uitstekend in die volgende woorde saam:

Als centraal kennisprincipe richt Gods Woordopenbaring zich tot 'het hart', het de tijdshorizon onzer ervaring transcenderende religieuze centrum van het menselijk bestaan. Zij werkt hier als een geestelijke drijfkracht in haar centraal grondthema van schepping, zondeval en verlossing, door Christus

4 Vir verdere verduideliking van hierdie punt kan Ouweneel (1993b:296-299) geraadpleeg word.

5 Ouweneel (1993b:299-300) verduidelik op die volgende wyse waarom die botydelike Woord van God nie van die tydelike Heilige Skrif geskei mag word nie: "The temporal and supratemporal ought never to be severed: every temporal word of Scripture has meaning only if considered within the scopus of the whole of the supratemporal Word ... We may apply Dooyeweerd's well-known prism and plant metaphor here: (a) The temporal words of Scripture form the diverging 'refraction' of the incomptible, eternal, central-religious Word of God; this Word is, conversely, the supratemporal point of concentration and integration ('focus') of all temporal words of Scripture. (b) The eternal Word of God is the supratemporal 'root-word', the various words of Scripture, which form its differentiation, are the temporal 'ramifications'. In no way are we allowed to create a dualism ... between the eternal Word of God and the various words of Scripture. As said before, the supratemporal Word of God diverges into all the various temporal words of Scripture, just like, conversely, the latter converge into the one Word of God. The various words of Scripture are the 'refraction' of the one Word of God itself, just like the one Word of God is the focus of the various words of Scripture themselves. The one Word of God is the whole of the various words of Scripture in their supratemporal fulness, unity and totality; the various words of Scripture are the Word of God in its temporal diversity and divergence. There is no room here for any dualism whatsoever." 
Die Christelike grondmotief en die Heilige Skrif by Dooyew'eerd

Jezus in de gemeenschap van de $\mathrm{H}$. Geest, dat de sleutel is tot de waarachtige Gods- en zelfkennis, en tegelijk de sleutel tot het verstaan van de $\mathrm{H}$. Schrift, zoals deze zich binnen de tijdelijke orde onzer ervaring aanbiedt.

In hierdie aanhaling kan gesien word dat die Woordopenbaring as sentrale kennisprinsipe hom tot die bo-tydelike religieuse sentrum van ons bestaan rig. Die Woordopenbaring as sentrale kennisprinsipe word onderskei van die Heilige Skrif wat binne die tydelike orde van ons ervaring gegee is. Dié onderskeid vind plaas deurdat Dooyeweerd die sentrale kennisprinsipe die sleutel tot die verstaan van die Skrif maak.

Uit die wyse waarop die onderskeid gestel word, skemer iets deur van die kardinale belang wat die bo-tydelike grondmotief as die Woord van God in sy sentrale religieuse sin vir die verstaan van die (temporele) Heilige Skrif het (vgl. Dooyeweerd, 1950:4; 1968:125). Wat verstaan Dooyeweerd met die term sleutel tot die verstaan van die Heilige Skrif? Hy (vergelyk Dooyeweerd, 1950:4; 1968:125) gebruik die woord sleutel in bogenoemde aanhaling met verwysing na woorde van Christus in sy gesprek met die Fariseërs en wetgeleerdes in Lukas 11:52. In dié gedeelte sê Christus die volgende aan hulle: "Ellende wag vir julle, wetgeleerdes, want julle het die sleutel van kennis weggeneem. Self het julle nie ingegaan nie, en dié wat wel wou ingaan, vir hulle het julle verhinder" (kursivering - JR). Hierdie 'sleutel van kennis' waarvan Christus praat, is volgens Dooyeweerd (1950:4) die Christelike grondmotief. Die grondmotief is ook die sleutel wat die hart van die mens oopsluit tot ware Gods- en selfkennis. Hierdie selfde sleutel sluit ook die hart oop om die geskrewe Woord te verstaan en om na dié Woord te luister.

Dooyeweerd se duidelikste verklaring van die term sleutel tot kennis word myns insiens in sy boek Roots of Western Culture gevind. Hy verduidelik die term soos volg (Dooyeweerd, 1979:95-96):

Holy Scripture signifies for us the true revelation of God's Word. This revelation can be understood only through faith guided by the Holy Spirit who operates in the religious ground motive of God's Word-revelation. If we read Scripture with an unbelieving heart we may indeed grasp the lingual meaning of its words and sentences, but their true faith meaning [geloofsbetekenis] escapes us ... Whoever does not understand the religious ground motive of Scripture lacks the key (kursivering - JR) to faith knowledge. This biblical ground motive is not a theoretical truth which one can understand scientifically. Rather, it is the all-controlling, dynamic power of God's Spirit who must open our hearts to what God has to say to us, and who, with our hearts thus opened, must unveil the faith meaning of Holy Writ. 
Uit dié anhaling blyk dit duidelik dat daar volgens Dooyeweerd twee vlakke vir die verstaan van die Skrif is. Die eerste vlak van verstaan is die ongelowige verstaan van die Skrif, die verstaan vanuit 'n hart wat deur 'n vreemde grondmotief beheer word. Sulke mense mag dalk die linguale betekenisse van die Skrif begryp, maar die ware geloofsbetekenis bly buite hulle bereik. Slegs die mense wie se hart deur die Christelike grondmotief oopgemaak is om God se Woord te ontvang, kan die ware geloofsbetekenis daarvan verstaan. Hierdie tweede vlak van verstaan is dus die gelowige verstaan van die Skrif. Vir hierdie verstaan is die Christelike grondmotief dus die sleutel.

Dit blyk dus dat die bo-tydelike Christelike grondmotief absoluut essensieel is vir die verstaan van die (temporele) Skrif. Die vraag wat nou ontstaan, is of die Christelike grondmotief van skepping, sondeval en verlossing deur Jesus Christus in gemeenskap met die Heilige Gees aan die Heilige Skrif ontleen word. Dooyeweerd (1950:4) stel dit onomwonde dat diegene wat van mening is dat die drieledige grondmotief slegs ' $n$ deel van die goddelike Woordopenbaring uitmaak, en dat die Wysbegeerte van die Wetsidee dit op 'n sekere willekeurige wyse uit die Heilige Skrif uitgelig het, glad nie die alomvattende sentrale betekenis van hierdie 'sleutel tot kennis' begryp nie. Daarmee saam lê hy ook klem daarop dat die Christelike grondmotief nie uit dogmatiese eksegese afgelei kan word nie, aangesien dit die Woord van God aan sekere subjektiewe feilbare interpretasies sal onderwerp (Dooyeweerd, 1960:104).

Dooyeweerd self (1962:14) stel dit so:

\begin{abstract}
De Wijsbegeerte der Wetsidee gaat ... er van uit dat het centrale, radicale en integrale motief van de Heilige Schrif, dat van schepping, zondeval en verlossing door Christus Jezus als het vlees-geworden Woord, als de sleutel der kennis, niet afhankelijk is van menslijke theologische interpretatie. Het staat niet ter beschikking van de mens, maar het beschikt over de mens. Zijn radicale geestelijke zin wordt rechtstreeks door de werking van de Heilige Geest aan de mens openbaar en niet door het intermediair van een feilbare theologische exegese van verschillende Schriftteksten, en van een theologische dogmatiek.
\end{abstract}

Uit dié aanhaling blyk dit dus duidelik dat die grondmotief vir Dooyeweerd nie ' $n$ saak van menslike uitleg is nie. Die mens staan nie in beheer daarvan nie, maar die grondmotief beheer die mens. In sy radikale geestelike sin word die grondmotief regstreeks deur die Heilige Gees aan die mens geopenbaar, sonder enige bemiddeling van feilbare menslike interpretasie. 
Die Christelike grondmotief en die Heilige Skrif by Dooyeweerd

Nog ' $n$ belangrike aspek wat hierby aansluit, is Dooyeweerd se wetenskapsteoretiese uitgangspunt dat die Wysbegeerte van die Wetsidee enige Christelike filosofie afwys wat vir intrinsieke wysgerige en wetenskaplike probleme en teorieë in spesifieke Bybeltekste steun soek (Dooyeweerd, 1950:3). ${ }^{6}$ Hy (1960:103) voel so sterk daaroor dat hy enige beroep op Bybeltekste ter ondersteuning van ' $n$ bepaalde wysgerige visie as uit die bose beskou. Die rede waarom hy so voel, is omdat dit daartoe lei dat aan sekere kwessies waaroor die Skrif uitdruklik praat, voorrang gegee word, terwyl oor ander sake waaroor die Skrif nie uitdruklike uitsprake lewer nie, enige standpunt gehuldig kan word, al word hierdie sake ook deur intrinsieke on-Skriftuurlike grondmotiewe gerig. Wanneer die innerlike aanknopingspunt tussen religie en filosofie nie raakgesien word nie, word ook nie begryp dat elke filosofie in 'n religieuse uitgangspunt (waarin 'n religieuse grondmotief werksaam is) gewortel is nie. Ook word nie bemerk dat die religieuse uitgangspunt die filosofie innerlik bepaal en sy probleemstellings beheers nie. Die opvatting wat Dooyeweerd hier verwerp, noem hy "Scholastische accommodatie" (Dooyeweerd, 1950:3).

Voor dié gedeelte afgesluit kan word, moet eers 'n laaste aspek van Dooyeweerd se verhouding tussen die grondmotief en die Skrif benadruk word. Sy tydsonderskeid is ook baie belangrik vir die verstaan van dié aspek. Vroeër is aangedui dat eenheid bo-tydelik is, terwyl verskeidenheid tydelik is. Volgens dié beginsel het die (bo-tydelike) Christelike grondmotief ' $n$ radikale eenheid wat ooreenstem met die radikale eenheid van die menslike bo-tydelike hart (Dooyeweerd, 1963:57; 1968:125). Hierteenoor sê Dooyeweerd dat die (tydelike) Heilige Skrif saamgestel is uit 'n groot verskeidenheid Bybelboeke wat deur verskillende mense deur die eeue heen geskryf is (Dooyeweerd, 1958:4; 1968:144). Wat maak dié verskeidenheid Bybelboeke tot 'n radikale geestelike eenheid?

6 Vollenhoven (1992:98) huldig 'n soortgelyke standpunt. Hy sê dat die Skrif nie eerstens wysgerig besig is nie, maar dat die Skrif hom in die eerste plek rig tot ons praktiese lewens. Klapwijk (1991:483-487) meen dat daar 'n verskil in die twee denkers se benadering tot die Skrif is. Vollenhoven het 'n baie meer direkte benadering en beklemtoon telkens dat filosofie in die lig van die Skrif beoefen moet word. Daarteenoor is Dooyeweerd baie versigtig om 'n direkte beroep op die Skrif te doen. Ouweneel (1986:320-321) toon egter aan dat Dooyeweerd se versig tigheid om hom direk op die Skrif te beroep 'n meer taktiese, as 'n prinsipiële besluit is. 
Dooyeweerd beantwoord die vraag soos volg $(1968: 123,125,144)$ :

In the human ego ... God had concentrated the entire meaning of the temporal world into a radical religious unity ... Thus the central theme of the Holy Scripture, namely, that of creation, fall into sin, and redemption by Jesus Christ in the communion of the Holy Spirit, has a radical unity of meaning, which is related to the central unity of our human existence ... What makes the diversity of books of the Old and New Testament into a radical spiritual unity? Their principle of unity can only be the central theme of creation, fall into sin, and redemption by Jesus Christ in communion of the Holy Spirit, since it is the key to true knowledge of God and self-knowledge. (Kursivering - JR.)

Dit blyk dus duidelik uit bogenoemde anhaling dat die verskeidenheid Bybelboeke slegs deur die Christelike grondmotief tot 'n radikale, geestelike eenheid gebring kan word. Dit is ook nie vreemd nie aangesien Dooyeweerd, soos vroeër aangetoon is, die Christelike grondmotief die Woord van God in sentrale religieuse sin noem. Die Heilige Skrif wat saamgestel is uit 'n groot verskeidenheid boeke is slegs die temporele vergestalting van hierdie bo-tydelike Woord van God.

Ouweneel (1993b:299) verduidelik die uitgangspunt dat die Heilige Skrif slegs die temporele vergestalting van die bo-tydelike Woord van God is as hy sê:

The eternal God has subjected man's supratemporal heart to his eternal, supratemporal Word. This is the sole and only Word, in its transcendent, integral meaning-fulness and -totality, which, within the temporal form of Scripture, diverges into many different 'words'. Just like the supratemporal heart expresses itself in many temporal functions, the one, undivided, eternal Word of God expresses itself in many words of Scripture. Just like there is not one function in human existence in which the heart does not express itself, there is not one word in Scripture in which the Word of God does not express itself. In his supratemporal, central-religious heart, man is therefore subject to the supratemporal, central-religious Word of God. In his temporal functioning, man is subject to various words of Scripture.

Daar kan dus uit bogenoemde aanhaling afgelei word dat die Woord van God in die sentrale religieuse sin die eenheid van die verskillende Bybelboeke is, aangesien die verskillende Bybelboeke die temporele vergestaltings van dié een ewige Woord is. Hierdie uitgangspunt kom ook duidelik na vore uit die volgende aanhaling van Dooyeweerd. Dié aanhaling bied ook 'n goeie samevatting van die verhouding tussen die Christelike grondmotief en die Heilige Skrif. Dooyeweerd sê (1958:4-5):

Het is alleen het centrale grondmotief, als goddelijke dunamis der $\mathrm{H}$. Schrift, dat de veelheid der bijbelboeken tot de eenheid der Godsopenbaring maakt. 
Die Christelike grondmotief en die Heilige Skrif by Dooyeweerd

En het is de sleutel der kennis, zonder welke alle schriftgeleerdheid dood en nutteloos is.

\section{Waardering en kritiek}

\subsection{Positiewe kritiek}

Dooyeweerd se onderskeid tussen die Woord van God in die sentrale religieuse sin en die geskrewe Woord (Heilige Skrif) is baie belangrik, aangesien hy op die wyse waarop hy die onderskeid uitgewerk het, reg kan laat geskied aan sowel die eenheid as die verskeidenheid van die Woord van God. In sy beskouing is daar ook 'n opvallende wisselwerking tussen die onderskeie Woorde van God. Aan die een kant wys die Heilige Skrif as tydelike geskrewe Woord van God daarop dat die Woord van God omvangryker as net die geskrewe Woord is (vgl. Ps. 147:15-18; Joh. 1:1, 14). Die Heilige Skrif is ook die sleutel wat ons in hierdie sondige bedeling moet gebruik om die Woord van God in al sy verskillende vergestaltings te verstaan (vgl. Strauss, 1984:117-118; Spykman, 1992:76-78). Aan die ander kant toon Dooyeweerd duidelik aan dat die geskrewe Woord nie 'werklik' verstaan kan word sonder dat die leser se hart deur die Woord van God in die sentrale religieuse sin oopgemaak is om die geskrewe Woord gelowig te aanvaar nie.

Daar moet ook waardering uitgespreek word vir die feit dat Dooyeweerd filosofies probeer verantwoord dat alle menslike handeling, wetenskap en filosofie ingesluit, religieus bepaald is. Filosofie is dus nie net ' $n$ formele handeling nie, maar 'n saak van die hart - daarom is die vraag na waar jou hart is (Matt. 6:21) ook van toepassing op die filosofie.

Dooyeweerd se klem op die belang van die Bybelse uitgangspunt van skepping, sondeval en verlossing vir 'n Christelike filosofie moet op prys gestel word. Met hierdie beklemtoning van die Bybelse uitgangspunt het hy diep insig getoon in die noodsaaklikheid van dié idees vir die Christenfilosoof. Dié idees lei die Christenfilosoof om nie in die tradisionele skynprobleme van die filosofie vas te val nie. So sien ons byvoorbeeld dat toe die moderne denkers die idee van die Skepper wat die subjek en objek in verhouding tot mekaar geskape het, laat vaar het, hulle probleme gehad het om die samehang van kennis te waarborg (vergelyk Venter, 1992?:17).

Dié idees is nie net van belang vir Christelike filosowe in hulle sistematiese werk nie, maar kan ook handig gebruik word in hulle bestudering van die 
J. Roets

geskiedenis van die filosofie. Die gebruik van die idees skepping, sondeval en verlossing in die bestudering van filosofiegeskiedenis word moontlik gemaak deur die feit dat dié idees sulke wesenlike elemente vorm dat selfs nie die voor- en anti-sintese (linkse) filosowe daaraan kon ontkom nie.

\subsection{Negatiewe kritiek}

Volgens Dooyeweerd is tyd die transendentale horison van teoretiese denke. Filosofie en wetenskap is teoretiese denke, en word dus altyd tot die temporele werklikheid beperk. Die Christelike grondmotief transendeer die tydelike werklikheid; daarom kan dié grondmotief nooit 'n objek van teoretiese denke wees nie. As teoretiese denke uitgebrei word dat die botydelike werklikheid ingesluit word, sal sodanige teoretiese denke volgens Dooyeweerd verval in ongesubstansieerde metafisiese spekulasies (Blosser, 1993:195).

Dooyeweerd se motivering vir hierdie bedenking is onaanvegbaar. Teenoor die meedoënlose pogings van die skolastisisme om die geheime dinge van God binne te dring, staan Dooyeweerd se poging om teoretiese denke tot ' $\mathrm{n}$ beskeie deel van ' $\mathrm{n}$ menslike toeganklike horison te beperk ( $\mathrm{vgl}$. Blosser, 1993:195-196). Sodoende het hy probeer om getrou te wees aan die Skrif wat leer dat die geheime dinge aan God behoort en die geopenbaarde dinge aan ons (vgl. Deut. 29:29).

Alhoewel Dooyeweerd se bedoelinge op hierdie punt onkritiseerbaar is, het die beperking van teoretiese denke sekere probleme veroorsaak - probleme met sy filosofie in die algemeen en in die besonder vir sy beskouing van die Christelike grondmotief. Blosser (1993:196) beskryf die probleem wat weens hierdie beperking van teoretiese denke met Dooyeweerd se filosofie in die algemeen ervaar word soos volg:

By carefully restricting the horizon of theoretical thought to the temporal horizon, Dooyeweerd endeavors to protect himself from metaphysical speculation. But the effect of this restriction is to preclude theoretical analysis and critique of his own view of the tempotal horizon and, ipso facto, of whatever in his view transcends it. If his own distinctive view of time and whatever transcends it - were itself an expression of metaphysical speculation, it could never be discovered by theoretical thought since theoretical thought itself is strictly limited to the temporal horizon as Dooyeweerd conceives it. In other words, we confront here something that resembles what a novelist once called 'Catch 22'.

In die aanhaling word dit duidelik gestel wat die algemene probleem met Dooyeweerd se teorie van die beperktheid van teoretiese denke is: hy wil 
Die Christelike grondnotief en die Heilige Skrif by Dooyeweerd

metafisiese spekulasie vermy, maar as daar enige reste van metafisiese spekulasie in Dooyeweerd se filosofie is, kan geen teoretiese kritiek daarop uitgeoefen word nie. Hierdie toedrag van sake gee daartoe aanleiding dat geen filosofiese kritiek op die bo-tydelike aspekte van Dooyeweerd se filosofie uitgeoefen kan word nie, aangesien filosofie as wetenskap beperk is tot die tydelike horison. Hierdie algemene probleem lei tot 'n mate van absolutisme in Dooyeweerd se filosofie.

Hierdie mate van absolutisme in Dooyeweerd se filosofie kan duidelik gesien word in sy visie van die Christelike grondmotief. Soos reeds gesien is, werk die grondmotief in op die bo-tydelike hart van die mens en is dus self bo-tydelik; daarom kan die grondmotief nie die voorwerp van teoretiese denke wees nie. Inteendeel - Dooyeweerd sê dat teoretiese denke deur 'n grondmotief beheer word. Volgens Dooyeweerd word Christene beheer deur die Christelike grondmotief van skepping, sondeval en verlossing deur Christus Jesus in gemeenskap met die Heilige Gees. Die wyse waarop Dooyeweerd die formulering van die Christelike grondmotief en sy visie op die grondmotiewe self verbind (vergelyk aanhalings op bladsye 263 en 264), lei daartoe dat sy formulering van die Christelike grondmotief nie gekritiseer kan word nie.

Daarom kan Olthuis (1985:35-35) die volgende oor die Christelike grondmotief by Dooyeweerd sê:

\begin{abstract}
He says we can only talk of the biblical ground motive when we have to do with the 'direct working of God's Word in the religious root of our life independent of all subjective human interpretation'. In acting as if his understanding of the presence of God's Word is direct and pure, Dooyeweerd tends to absolutize his views. In effect his view is nonnegotiable and discussion about the validity of (his view of) the biblical ground motive is illegitimate.
\end{abstract}

Of Olthuis Dooyeweerd korrek weergegee het, is nie hier tersprake nie. Olthuis is egter getrou in sy weergawe van die indruk van absolutisme wat ons vind by Dooyeweerd in sy hantering van die Christelike grondmotief. Die probleem met Dooyeweerd is dat hy nie 'n duidelike onderskeid maak tussen sy formulering van die grondmotief, die wysgerige besinning oor die grondmotief en die grondmotief self nie. Oor die formulering van en die wysgerige besinning oor die grondmotief kan gediskusseer word - die grondmotief self is egter ononderhandelbaar (Troost, 1983:30). Die formulering van die Christelike grondmotief is altyd 'n gebrekkige menslike poging (vergelyk Ouweneel, 1993b:372); daarom moet die formulering altyd oop staan vir verfyning en korreksie. Dieselfde geld vir 
die wysgerige besinning oor die grondmotiewe. Hierteenoor staan die ononderhandelbaarheid van die grondmotief self wat inwerk op die hart, die religieuse worteleenheid van die mens, óf as God se Woord deur die Heilige Gees, óf as afvallige gees.

Deur hierdie onderskeid kan die essensiële van Dooyeweerd se siening van die Christelike grondmotief as Woord van God behou word en die mate van absolutisme wat in sy beskouing na vore gekom het, uit die weg geruim word.

\section{Konklusie}

$\mathrm{Na}$ aanleiding van alles wat hierbo gesê is, kan ons Dooyeweerd se visie op die verhouding tussen die Christelike grondmotief en die Heilige Skrif soos volg saamvat:

* Die Christelike grondmotief is as grondmotief bo-tydelik en daarom ook bo-teoreties. Dit beheer egter alle wetenskaplike denke deurdat dit beslag lê op die bo-tydelike hart van die mens. Daarom is die Christelike grondmotief self nie 'n geloofstuk of dogma nie (menslike formuleringe), maar die goddelike dryfveer wat ook aan alle geloofstukke en dogmas gees en lewe gee.

* Die Christelike grondmotief as die Woord van God in sy sentrale religieuse sin is die een, ewige, onverdeelde Woord van God, terwyl die Heilige Skrif die temporele vergestalting van hierdie een, ewige, onverdeelde Woord van God is. Daarom kan Dooyeweerd sê dat die Christelike grondmotief die sentrale kennisprinsipe van die Heilige Skrif is en dat dié motief ook die ses en sestig verskillende Bybelboeke tot 'n ryke verskeidenheid saambind.

\section{Bibliografie}

BLOSSER, P. 1993. Reconnoitering Dooyeweerd's Theory of Man. Philosophia Reformata, 58:192-209.

BYBEL. 1983. Die Bybel: nuwe vertaling. Kaapstad : Bybelgenootskap van Suid-Afrika.

DOOYEWEERD, H. 1950. De strijd om het schriftuurlijk karakter van de Wijsbegeerte der Wetsidee. Mededeelingen van de Vereeniging voor Calvinistich Wijshegeerte: 3-6, Jul.

DOOYEWEERD, H. 1957. A New Critique of Theoretical Thought. Deel 1. Amsterdam : Paris. $566 \mathrm{p}$.

DOOYEWEERD, H. 1958. De verhouding tussen wijsbegeerte en theologie en de strijd der faculteiten. Philosophia Reformata, 23:1-21. 
Die Christelike grondmotief en die Heilige Shrif by Dooyeweerd

DOOYEWEERD, H. 1960. Van Peursen's critische vragen bij "A New Critique of Theoretical Thought". Philosophia Reformata, 25:97-150.

DOOYEWEERD, H. 1962. Verkenningen in de wijsbegeerte, de sociologie en de rechtsgeschiedenis. Amsterdam : Buijten \& Schipperheijn. 215 p. (Reeks: Christelijk perspectief. Deel 1.)

DOOYEWEERD, H. 1968. In the Twilight of Western Thought. Philadelphia : Presbyterian and Reformed. $194 \mathrm{p}$.

DOOYEWEERD, H. 1979. Roots of Western Culture. Toronto : Wedge. $228 \mathrm{p}$.

DOOYEWEERD, H. 1980. Comelius van Til and the Transcendental Critique of Theoretical Thought. (In Geehan, E.R., ed. Jerusalem and Athens. Phillipsburg, N.J. : Presbyterian and Reformed. p. 74-89.)

DUVENAGE, B. 1984. Die plek van die Skrif in die wetenskap - enkele riglyne uit die reformatoriese tradisie. (In Wetenskap en Woord: 'n bundel voordragte saamgestel deur die Departement Wetenskapsleer. Potchefstroom : PU vir CHO. p. 47-66. Reeks J1: Wetenskap In U Lig. Nr. 3. Deel 1.)

HENDRIKSEN, W. 1991. 1 \& 2 Timothy and Titus. Edinburgh : The Banner of Truth Trust. $403 \mathrm{p}$.

KLAPWIJK, J. 1991. Reformational Philosophy on the Boundary between the Past and the Future. (In The Idea of Reform. Potchefstroom : PU vir CHO. p. 476-526. Institute of Reformational Studies. Reeks F3. Nr. 41.)

KRAAY, J.N. 1980. Successive Conceptions in the Development of the Christian Philosophy of Herman Dooyeweerd (II). Philosophia Reformata, $45(1): 1-46$.

OLTHUIS, J.H. 1985. Dooyeweerd on Religion and Faith. (In Mcintire, C.T., $e d$. The Legacy of Herman Dooyeweerd. London : University Press of America. p. 21-40.)

OUWENEEL, W.J. 1986. De leer van de mens. Amsterdam : Buijten \& Schipperheijn. $455 \mathrm{p}$.

OUWENEEL, W.J. 1993a. Supratemporality in the Trancendental Anthropology of Herman Dooyeweerd. Philosophia Reformata, 58:210-220.

OUWENEEL, W.J. 1993b. A Critical Analysis of the External and Internal Prolegomena of Systematic Theology. Bloemfontein : Universiteit van die Oranje-Vrystaat. (D. Th. - proefskrif.) 443 p.

SPYKMAN, G.J. 1992. Reformational Theology : A New Paradigm for Doing Dogmatics. Grand Rapids, Mich. : Eerdmans. 584 p.

STRAUSS, D.F.M. 1984. Die gedifferensieerdheid van die Woord van God. Tydskrif vir Christelike Wetenskap, 20:3-4; 115-128.

TROOST, A. 1983. Theologische misverstanden inzake een Reformatorische Wijsbegeerte (IIl, slot). Philosophia Reformata, 48:19-49.

VENTER, J.J. 1992?. Klasaantekeninge oor die moderne filosofie (FIL 321). Potchefstroom. 107 p. (Ongepubliseer.) 
VOLLENHOVEN, D.H.Th. 1992. Schriftgebruik en wijsbegeerte. (In Tol, A. \& Bril, K.A., reds. Vollenhoven als wijsgeer. Amsterdam : Buijten \& Schipperheijn. p. 97-106.) 
